$\begin{array}{r}\text { Volume and Issues Obtainable at Center for Sustainability Research and Consultancy } \\ \text { Journal of Business and Social Review in Emerging Economies } \\ \text { ISSN: 2519-089X (E): 2519-0326 } \\ \text { Volume 6: No. 3, September 2020 } \\ \text { JSRᄃ } \\ \text { Journal homepage: www.publishing.globalcsrc.org/jbsee } \\ \hline\end{array}$

\title{
The Curse of Vagrancy in Pakistan
}

\section{${ }^{1}$ Ume Laila, ${ }^{2}$ Najma Sadiq, ${ }^{3}$ Tahir Mehmood, ${ }^{4}$ Muhammad Farhan Fiaz}

${ }^{1}$ Assistant Professor, Government \& Public Policy, School of Social Sciences and Humanities (S3H), National University of Sciences and Technology (NUST), Islamabad, Pakistan, dr.umelaila@ s3h.nust.edu.pk

${ }^{2}$ Assistant Professor, Head of the Department, Department of Mass Communication, School of Social Sciences and Humanities (S3H), National University of Sciences and Technology (NUST), Islamabad, Pakistan, najma.sadiq@s3h.nust.edu.pk

${ }^{3}$ Assistant Professor, Department of Communication studies, BahaUddin Zakariya University, Multan, Pakistan, tahirmahmood@bzu.edu.pk

${ }^{4}$ Visiting Faculty, School of Social Sciences and Humanities (S3H) H-12 Sector, National University of Sciences and Technology (NUST), Islamabad, Pakistan, farhankdi9@gmail.com

\begin{tabular}{l} 
ARTICLE DETAILS \\
\hline History \\
Revised format: August 2020 \\
Available Online: September \\
2020
\end{tabular}

\section{Keywords}

Vagrancy, Poverty,

Homelessness, Begging

\section{JEL Classification}

M10, M19

\section{ABSTRACT}

Poverty and Vagrancy are an interlinked phenomenon, and the boundaries are blur as to which one leads to the other. Among many social issues, Pakistan faces the challenge of homelessness to date. The ratio of vagrancy and beggars is higher in the poorer provinces, which leads to unavoidable and difficult circumstances. The terms Vagrancy and begging, often interchanged, are analyzed in the following study, in addition to the legal steps taken for curbing it - not through occasional police crackdowns, but rather through well-established mechanisms.

\section{OPEN ACCESS}

(C) 2020 Center for Sustainability Research and Consultancy Pakistan under a Creative Commons Attribution-NonCommercial-ShareAlike 4.0

Corresponding author's email address: dr.umelaila@s3h.nust.edu.pk

Recommended citation: Laila, U., Sadiq, N., Mehmood, T. \& Fiaz, M. F. (2020). The curse of Vagrancy in Pakistan. Journal of Business and Social Review in Emerging Economies, 6(3), 1211-1220

\section{Introduction}

Since its inception, Pakistan has faced many challenges which has had drastic impacts. Poverty is one of the most significant outcomes, which is linked to a plethora of issues. One of the most prevailing impacts of poverty is vagrancy. Through centuries, countries have been facing the problem of rough sleepers and people occupying streets to sleep. In 1824, the United Kingdom, through a Vagrancy Act declared sleeping in deserted or unoccupied buildings, in wagons/ carts, on streets as criminal offence. ${ }^{i}$

According to Britannica, Vagrancy is defined as a "state or action of one who has no established home and drifts from place to place without visible or lawful means of support. Traditionally, a vagrant was thought to be one who was able to work for his maintenance but preferred instead to live idly, often as a beggar". ii The terms Vagrant and Beggar are often used interchangeably, subsequently resulting in legislation which is vague. For the purpose of this research, both vagrants and beggars are being considered as an underprivileged segment of the society who need to be supported as victims rather than criminals. The segment targeted are those people who are homeless, with or without employment. 
An extensive research through a DFID study has defined vagrancy/ homelessness with a wide spectrum, in line with the United Nations definition, "Homelessness includes people living in many different situations, from abject shelterlessness and street sleeping through to those living in extremely inadequate accommodation, which could be said not to provide the qualities of home." "iii The United Nations elaborated that being homeless does not only mean living and sleeping on the street, or a state provided shelter, rather it also means living in a place that lacks the basic necessities of life, including lack of personal security, food, education and health facilities.

Homelessness is a difficult situation which can give birth to a wide range of issues, including social exclusion, health problems, attainment of education, right to justice, etc. ${ }^{\text {iv }}$ More often than not they are victim of the crimes rather than its perpetrators. The causes of homelessness are very complex, and depends on person to person case, which shall further be described in this paper. It is also important to understand the multifaceted impacts that homelessness has not only on those suffering from it but also on the society, because the fact that homelessness in a society is due to a defect in that society cannot be ignored.

In Pakistan, the vagrancy and begging ratio is very high. From beggars being found on every other signal to vagrants sleeping on footpaths, the number of beggars has increased over the last few decades. ${ }^{\mathrm{V}}$ According to UN reports, more than 20 million people in Pakistan are homeless, with the highest ratio in Baluchistan and erstwhile FATA.

This paper analyzes the root causes of vagrancy and its impact, with reference to the present legislation regarding vagrancy in Pakistan at provincial levels. The implementation gaps in execution of these laws is elaborated extensively with the reasons leading to widespread vagrancy, and their solutions as adopted by other developing countries are also mentioned. It is to be noted that the curse of vagrancy is borne by every developing country in complex dynamics, and while each country is struggling with the issue of homelessness, they will only succeed to weed out this problem if they identify root causes and legislate with a vision of long-term development.

\subsection{What Leads to Vagrancy and What it Leads to?}

Vagrancy covers a wide spectrum which does not only have one reason. Homelessness can be pursued as a result of various factors. An analysis of case to case basis will highlight the choices or circumstances of each individual that resulted in homelessness. This can be due to an individual's own impulsive personality, or due to unhealthy family norms, or sexual/ physical abuse. Certain communities have a high unemployment ratio due to which affordability decreases and homelessness increases. A more general overview suggests that when inequality in a society rises, and weak government policies exist, homelessness is bound to prevail.

In Pakistan, there are many factors that lead to an individual's choice of being homeless. From being a marginally poor economy, Pakistan has also suffered from various natural and manmade disasters. To name a few, terrorism, floods, immigrants and multi-dimensional poverty are at the top of the list.

Poverty is one of the underlying factors of vagrancy. $35 \%$ of Pakistan's population is estimated to be living under the national poverty line ${ }^{\mathrm{vi}}$, out of which $13 \%$ reside in urban areas and $31 \%$ in rural areas. ${ }^{\text {vii }}$ According to a recent report of UNDP, around 39\% of Pakistan's population live in multi-dimensional poverty. It is not only prevalent all across the country but disparities also exist across the provinces. Over $70 \%$ population lives in multidimensional poverty in Baluchistan and erstwhile FATA, with people in Khyber Pakhtunkhwa and Sindh close at $49 \%$ and $43 \%$ respectively. $31 \%$ people in Punjab and $25 \%$ in Azad Jammu and Kashmir live in multidimensional poverty. ${ }^{\text {viii }}$

When poverty is coupled with unemployment, it becomes a basis for ultimate vagrancy. Begging becomes the only source for providing the family, which usually is large. Since begging becomes a norm for these families, they reproduce more to get more hands to beg and earn a living. This generational begging leads to a network of vagrancy. Even if a member wants to separate from their families to leave begging, they do not have a choice, since zero skills and no other source of income forces them to stay in the network. ${ }^{\text {ix }}$

Pakistan has faced drastic measures since the War of terror, and unfortunately one of the main impacts has been homelessness, poverty and ultimately begging has been the last resort. Due to internally displaced people, many cases 
of kidnappings and abductions have also been reported. These kidnappings of women and children were with a purpose to use the victims as beggars ${ }^{\mathrm{x}}$. Military operations carried out in the tribal and surrounding districts drove people out of their homes. With only a few resources, many settles around major cities, which increased the begging ration especially those of children.

Another major reason for the increase in begging over the past few decades is the Afghan immigrants, as a result of the Afghan War. The large-scale impact of the conflict followed by Soviet invasion of Afghanistan cannot be ignored. Many immigrants settled in Peshawar in different vicinities, and upon different terms. Only some could afford the luxury of renting homes, and many had to live in conditions similar to slums. The main source of income was beggary for them which contributed to the rise in ratio of beggary in the province ${ }^{\mathrm{xi}}$.

Pakistan also hosts a large number of gypsies in its territory. Though, in interpretation gypsies are not termed as homeless people, but in reality, they are without a real home. They move from one place to another periodically and settle on abandoned lands at outskirts of cities or towns for better opportunities. Gypsies remain in their own community throughout their lives; however, studies lack evidence the patterns they follow in their life to earn a living. It is to be noted that not all vagrants are beggars, and not all beggars are vagrants. Pakistan has many economic hubs especially the capital cities of each province in which employment and labor are concentrated while the periphery cities or towns have less opportunities. This causes labors to move from peripheries to these concentration units in search of a livelihood, but unable to afford accommodation in these expensive areas, they choose the street-life.

In more advanced societies, education is also a core reason for being homeless. However, the dynamics in Pakistan are different. Although attaining education is very important, in an agricultural society, it doesn't have to be the only source towards prosperity, and leading businessmen have proven that. Though Pakistan has a low literacy rate, the main reason that leads to homelessness is the inequality in the society. Wealth is unequally distributed and the gap between the rich and the poor is only expanding.

The uncertain and rapid population growth also contributes to the increase in poverty. In developing nations, there is no mechanism to control population which results in chronic problems of housing shortages and constrained resources for the population equally. Since developing nations have unstable fiscal systems and weak governance mechanism, the rapid population growth only adds to the problem of homelessness.

Addiction to narcotics can also be deemed as a cause of homelessness. Not only does addiction exhausts all the resources of an individual, rather it is also considered as a social evil in society which can lead to a person being homeless. Addiction can both be a cause and effect of homelessness, but in any case, homelessness is the common factor.

Homeless people develop chronic illnesses, or severe diseases due to poor weather and living conditions. They are exposed to fumes and pollution throughout the day, with no facilitation to hygiene, and eat off of scrapes of garbage. Physical illnesses aside, homeless people have shown psychological symptoms as well - behavioral disorders, anxiety and depression are prevalent among them ${ }^{\mathrm{xii}}$.

Homeless people are also prone to violence. They can both be the perpetrators of violence and the victims as well. Since they do not have a source of income, they might involve in crimes such as theft, kidnapping or murder. On the other hand, they also may be abused physically, sexually ${ }^{x i i}$, economically or psychologically while on the streets. Many groups in Pakistan have made a job out of begging by using the underprivileged and homeless people. It earns them an immoral income and provides for scrapes for the homeless.

\subsection{Legislation regarding Vagrancy in Pakistan}

The Sind Vagrancy Act 1947 was the first of its kind of legislation in any territory of Pakistan, which provided for the welfare of vagrants in the province of Sindh. This Act was repealed by the West Pakistan Vagrancy Ordinance, 1958. In the Ordinance, vagrant is defined as a person who receives charities in a public place, or exhibits wounds or sores for the purpose of receiving charity. 
Under this Ordinance, the government is directed to provide welfare homes for the vagrants to be placed under custody and detention. Managers shall be appointed for the provision of medical needs of vagrants and priority for the education and rehabilitation of children. The Ordinance empowers police to arrest prospective vagrants with the authority to seize anything found on the person. Vagrants shall, however have the right of fair trial before the magistrate. Vagrants found guilty will serve their term in welfare homes, not exceeding a term of three years.

Currently, three provinces in Pakistan have adopted the same Ordinance under the respective name of their province. Only Khyber Pakhtunkhwa has repealed the law through the enactment of another Act.

In Sindh, the West Pakistan Vagrancy Ordinance, 1958 was adopted under the name of Sindh Vagrancy Ordinance, 1958, through the Sindh Vagrancy (Amendment) Ordinance, 1983. The provisions are similar to The West Pakistan Vagrancy Ordinance, 1958, except a few minor changes. This Amendment also repealed The Vagrancy (Karachi Division) Act, 1950.

The Governor of Baluchistan through an enactment adopted the West Pakistan Vagrancy Ordinance, 1958 in 1975 , under the name of The Baluchistan Vagrancy Ordinance, 1958. The provisions of this Ordinance are the same as that of The West Pakistan Vagrancy Ordinance, however some changes have been made regarding the sentence for the guilty.

The Governor of Punjab through an enactment of the Ordinance adopted the West Pakistan Vagrancy Ordinance, 1958 in 1974. The Ordinance was henceforth known as The Punjab Vagrancy Ordinance, 1958, with the provisions almost similar to The West Pakistan Vagrancy Ordinance, 1958.

The Khyber Pakhtunkhwa Child Protection and Welfare Act, 2010 primarily deals with the protection of children. The Act provides for the children to be prevented from begging, being homeless, used in acts of prostitution/ pornography, or trafficking etc. Through this Act, the Provincial government is empowered to prohibit the employment of children and has defined the punishments liable on the persons who violate this law. The Act also provides for the welfare education to children. However, this Act repealed The West Pakistan Vagrancy Ordinance, 1958.

\subsection{Implementation Gaps in Execution of the Relevant Legislation}

No province of Pakistan, except Khyber Pakhtunkhwa has repealed the West-Pakistan Vagrancy Ordinance, 1958 - an ordinance that deems vagrants to be criminals rather than victims. Under section 7 of the said Ordinance empowers police officers to arrest or search any person who appears to be a beggar or seize anything found on them without the order from a magistrate or a warrant. The executive takes responsibility for the welfare of these vagrants rather than punishing them but where is the implementation?

The Khyber Pakhtunkhwa Child Welfare and Protection Act, 2010 has secured and provided protection to the children of Khyber Pakhtunkhwa against begging, harassment, abuse, and trafficking, etc. Although it is not implemented in its spirit, and the province is left without a Vagrancy law for adults, it still has shown progress on the subject unlike the rest of the provinces. The 2017 statistics of the Government of Khyber Pakhtunkhwa Zakat Ushr, Social Welfare, Special Education and Women Empowerment Department claims the establishment of 12 Welfare Homes whose mandate is to control beggary and drug addiction in children. Scattered in different districts of the province, the total strength of children in these welfare homes adds up to 367. Under the department, 3 Daraul Kafalas have also been established which catered to 560 people. The mandate is to rehabilitate beggars by providing services and vocational training in tailoring. Moreover, 9 rehabilitation centers for drug addicts were established all across the province in different districts, out which only 7 are functional. Since 2014, more than 500 drug addicts were rehabilitated each year, and trainings have been imparted to more than 130 people ${ }^{1}$.

According to a study conducted in Peshawar, child beggars and vagrants are arrested in Peshawar, which in itself is a 
violation of the Child Welfare and Protection Act, 2010. However, when they are brought to the Welfare Homes, the insufficient services and lack of staff releases local child beggars at once. If they are from another district, only then they are kept at the welfare homes. Moreover, they are released after 5 to 6 weeks with no formal education or skill imparted upon them which again motivated them towards begging. Despite efforts being put by the provincial government, the bureaucracy blames the lack of inter-departmental coordination for the implementation gaps. Every department works in isolation which creates many hurdles in effective operations ${ }^{\mathrm{xiv}}$.

The Government of Punjab took a step towards eradicating beggary by establishing a Beggar's Home under the Department of Social Welfare in 2014 in Lahore. Beggars captured by police are brought to the Beggar's home and after verification and authorization they are admitted for rehabilitation. Children captured by police are referred to Child Protection Bureau. Though providing a variety of facilities like medical treatment, vocational training, religious education, rehabilitation and legal support but the capacity of Beggar's Home is only 50 people at a time ${ }^{\mathrm{xv}}$. However, it has been reported that in past two years, no beggar has been brought to the facility even though the staff is ready to deliver. After the publication of this news, the Chief Minister announced a crackdown on beggars in the city to ensure traffic in the Beggar's Home. It is unfortunate to mention that such actions have to be taken while the faults lie in coordination among departments. Other set ups such as Darul Khilafah and Darul Shafqat have been established for vagrants but practically it has provided no support to vagrants. The project for a welfare home for beggars in Faisalabad district was approved in 2015, however the funds have still not been released.

In Karachi, a recent case of banning 50 spots in the city to beggars arose, which gave rise to the question of welfare homes in the province. Beggars in the city are arrested by the police and brought before courts, where judges only impose fines on them. The Chief Secretary of the province has been time and again approached for the establishment of welfare homes for beggars, however no heed has been given to this matter.

In Balochistan, the Social Welfare Department has established 2 centers for senior citizens who are homeless, and 2 facilities known as Darul Aman for homeless women. Even though the department acknowledges the rehabilitation of beggars, there is no data available. For such a large province, the facilities available are very less. The population of the province is spread far and wide, which cannot be catered with such limited facilities.

\subsection{Identification of the Vagrant Population and their Nature}

Beggars and vagrants are certainly not decreasing in numbers, rather increasing. They roam around every signal and major road in cities in Pakistan. When many complaints are submitted, a crackdown begins for the removal of these beggars. However, the government never analyzes the reason why the vagrants and beggars are on the roads in the first place, rather arrests and harass them. The solution for abolition of vagrancy and beggary is not occasional crackdowns, but established welfare centers to provide shelter, health and food facilities to the underprivileged. Many believe that implementation of the vagrancy law and abolishment of child beggary cannot end because the officials are paid by the begging mafia to remain quiet. It is important for government organizations, after intimating relevant departments and civil society, to legislate for the vagrants, and with appropriate coordination among all stakeholders, implement the policies as well. Following are a few steps the government needs to take before making policies and laws for vagrants in the country.

\subsection{Define and Count the Vagrants}

The foremost step for the government is to define the term "vagrant", which is applicable across the entire country. Begging and vagrancy should be differentiated and bot the issues should be dealt with after finding out the root causes. It is also not appropriate to adopt western developed countries' definitions for homelessness and beggary, because they do not in developing countries. Developing countries vary from each other as well, and especially Pakistan whose history is rich with differences between ethnicities, sects and language. Policymakers should take all relevant stakeholders, including representatives of civil society, non-governmental organizations and private sector to identify the individuals that can be termed as vagrants and beggars.

The second most important step for the government is to have a database which presents the accurate number of vagrants and beggars in the country. No policy or law can be applicable if the number of a certain community for 
whom the law is made, is not accurate. Pakistan does not have any accurate figure of the beggars or vagrants, since very many complexities in identifying vagrants has been seen. The policymakers of the country need to ensure that they develop a mechanism to carry out homelessness and beggars census, with the help of non-governmental and notfor-profit organizations. This process will streamline the present laws and policies enacted for the purpose of reducing vagrancy, as it will present an estimate of budget for providing services, constructing special homes and land allocation to cater vagrants.

\subsection{Vagrants, Beggars and Squatters}

The need to define vagrancy with a common definition across the country will be highly useful because it will create a distinction between homeless, beggars and squatters. Squatters are the people who occupy an abandoned house, building or land for a certain period of time, while they do not actually own it. Squatters may move from one place to another from time to time - they do not have a home, but they are also not as desperate as the vagrants on streets with no resources at all. The total number of vagrants, beggars and squatters together will overwhelm the policymakers and it will become a tedious task to cater to the masses altogether.

Policymakers should focus on distinguishing these groups in order to make a comprehensive and effective plan for vagrants.

\subsection{Identification of Gypsies/ Nomads}

The concept of nomadism and gypsies is centuries old - almost as old as the human civilization. Gypsies travel from one place to another on a periodic basis in hope of finding a better life. The major incentives for them to move from one place to another is to find better resources, better wages and a better settlement. Pakistan, like every other country in the world has a large population of gypsies. Though they were not represented in the census 2017, a nongovernment organization in Lahore has estimated the numbers of gypsies to be around 10 million. This is a huge figure, which makes up to $5 \%$ of the total population of Pakistan, however they are marginally deprived of basic rights and identification. Without the Computerized national identity cards $(\mathrm{CNICs})^{\mathrm{xvi}}$, their existence to the state is only a bleak reality, as they remain deprived of any state service. Lack of education and poverty is prevalent in these communities, who often migrate from one part of a region to another in search of low-income odd jobs such as cleaning, juggling, selling mud toys, etc. The harsh reality of these communities is that they have failed to evolve with the rest of the citizens of the world. They still are dependent on their old customs and ways for making a living, which is depleting because people are no more interested in buying their mud toys or see them juggling. This has led to a massive amount of people from the gypsy community to turn towards beggary. Gypsies usually settle around urban areas, for the purpose of seeking a daily-wage job or generate income through begging. Women in the gypsy community has also reverted to generating income through sex-working. This has led to them developing many communicable diseases such as HIV/ AIDs.

There is no doubt that the gypsy community makes a big chunk of our population, and their basic rights cannot be ignored whole making policies for the citizens. An accurate census shall be held for the nomad communities, and by involving NGOs and civil society, proper legislation shall be done for them as well. It should also be identified whether they belong to the vagrant community or not. This community cannot be ignored, because as long as nomads do not get their rights, they will remain in the community as beggars or vagrants which will not solve the issue of vagrancy at all.

\subsection{Legal Position of Vagrants}

The most common response to vagrants across the globe has been to remove them from the vicinity. Even the legislation regarding vagrants reflect the precise idea of removing them from the streets, and in some occasions imprisoning them or developing homes for them. It is not possible to remove such a huge number of people from the streets and with limited facilities such as Dar ul kafalas, they cannot be accommodated. Removing them from the vicinity by force is only an artificial or cosmetic solution because either they return when the rules are relaxed or they move to another area. The root cause of vagrancy ahs to be identified and then a mechanism has to be developed to cater them, because they cannot be deemed illegal and punished just because they are poor and homeless. It is the responsibility of the state to cater to the needs of all citizens alike. 


\subsection{Policy Interventions by Developing Countries}

In most developing countries, squatters, vagrants and beggars are dealt with brutal force, eviction or arrest. The most vulnerable to these brutalities are children and women. Even though Article 40 of UNCRC has been endorsed in theory by all the developing countries, which stresses on child imprisonment being the last resort of any misdemeanor, police in developing countries practice it on daily basis in their raids. Areas concentrated with vagrants and beggars have become notorious, because of the unpleasant experience created by eviction drives and police raids. Some developing countries have started providing transit camps or welfare homes to vagrants, but due to the lack of proper fund and facilitation. The problem cannot be contained. In Zimbabwe, transit camps have been established which caters to 30,000 vagrants, but due to lack of consistency in providing facilitation, these camps are unable to function as expected. Mortality rate and poverty thrives in such areas which ultimately reflects on the nearby urban units.

Some developing countries, such as Peru and Egypt have reverted to providing valueless government owned land to the vagrants for a long period of time, and eventually plan to let the vagrants legally accumulate the land. However, for an extended period the vagrants do not have any assurance whether they will come to own the land they have been allotted to live. This anticipation coupled with no opportunity to earn and extreme poverty indulges the vagrants towards begging or other crimes. Many developing countries have legislated especially focusing on juveniles or minors, to reduce street children and beggary. After they are arrested, children are sent to institutions or designated hostels to be reformed. This increases their chances of damaged emotional and mental health, as children do not have the cognitive ability to identify what is good or bad for them; and at such a tender age, alienating them in institutions can be more damaging than beneficial. Facts and figures are the evidence that developing countries cannot provide institutions that provide basic facilities to children, including fulfilling their hunger, health and education requirements.

In developing countries, the response to any problem creates a struggle between the providers and the takers. In Bangalore, India a project was initiated for child vagrants to provide them with education, accommodation and train them to seek employment opportunities. This program reached success level with days and the available slots filled up - however, there was a catch. Some parents started sending their children/ or abandoning their children for the sake of accumulating better opportunities. While this program was originally initiated for homeless children with no families, different segments of the society started reverting to it, which snatched away the opportunity created for homeless children. Moreover, it was reported that children stole from the institution and would run off once they had enough money, only to return empty-handed and in need again.

The above example declares that not everything resides in the hands of the state. Certain cultural, social and economical situations of a community tend them to act in a certain manner, and upon the intervention of the state, a social hiatus breaks out among the segments of the society. A comprehensive solution to the problem of vagrancy cannot be identified unless the state addresses the root issue, i.e.; poverty and lack of education in most cases.

\subsection{How can Pakistan Fight Vagrancy?}

Pakistan is a financially weak country. It depends upon foreign loans and foreign funding for making ends meet every financial year. Numerous NGOs and foreign funded projects operate in Pakistan to uplift the social status of marginalized citizens, because the government alone cannot cater to them. Similarly, eliminating or addressing the curse of vagrancy in Pakistan cannot be dealt with by the government alone. Even if they make laws, there is no postlegislative scrutiny mechanism to see to the law whether it is implemented or not. Besides, the state has many other pressing issues to address, than to look towards the most discriminated class of the society: the vagrants, beggars and gypsies. This marginalized class of society has been deprived of basic rights such as education, health and identification since generations, and it can only be estimated what their actual number is. Such a huge community cannot be catered through welfare means. A policy needs to be developed for this community to be integrated in the society as the working class. Similarly, the general perception of homeless people as unemployed, addicted and criminals need to be eliminated from the society. Police brutality towards vagrants further imprints the image of homeless people as criminals or menace in the minds of the better privileged classes. Mainstream and social media also plays a pivotal role in promoting this image, which can only be remitted by extensive research and legislation, 
involving all relevant stakeholders including the vagrants, civil society and NGOs.

It is essential to reach out to vagrants and the gypsies to secure their view regarding an effective policy. It will help identify their differing needs of food, shelter, jobs or identification. Basic necessities should be catered to first, to control crime rates, and then further deliberate on the rehabilitation step to make these citizens able to earn for themselves.

The gypsy community has lived their lives as immigrants and squatters for generations. They are also known for having skills and talents particular to their area, e.g.; Jogis are talented to entertain people with Snakes, the Bagri Caste is known for farming and gardening, the Oudh caste is skilled with making mud-houses, and the Kabootra caste is known for having gymnastics tactics. For centuries, these castes have made a living with these talents and skills, however, due to the technological advancements, these skills have become useless to earn a living, and hence gypsies have reverted to begging or in some cases crimes. Unlike professional beggars, gypsies are equipped with the talent of earning for themselves through any means available to them. This should be seen as a huge opportunity by the government while legislating a policy for the gypsies. After providing them identification, they can be integrated in the society as working class, albeit after equipping them with skills and training. Capacity building programs and drives will enable men and women alike from the gypsy community to raise from generational poverty, as they would start earning for themselves.

Gypsies do not hold national identity cards in Pakistan currently, which alienates them from the national census or any form of legislation. Since they do not have any identity, it becomes stringent for them to attain a suitable job. If the grassroot problem is identified and catered to, the government will be able to provide better facilities to the gypsy community.

Similarly, vagrants, squatters and beggars need immediate relief in form of shelter, food and medical attention. Only after their basic necessities are fulfilled, they will turn towards job opportunities. The government should design relief programs for vagrants in such a way that the shelter provided to them is free at first, but gradually as they seek jobs and earn an income, they should start paying rent - this will make the government relief schemes more sustainable and effective. Moreover, such shelters/ homes shall be located near sources of work, which will be an added incentive for the vagrants not to sleep on footpaths or greenbelts.

In Pakistan, even though legislation has been done in each provincial legislature with respect to vagrants, which identifies them and provides for welfare homes to cater vagrants, the bottleneck arises during the implementation process. A major hindrance in this respect is the lack of data available, which can chalk out the actual estimate of vagrants and beggars in the country. Moreover, no effective delegated legislation has been done regarding the vagrancy laws in Pakistan, which automatically makes a law ineffective. There is no inter-departmental coordination which can micromanage the cases of each individual vagrant - and establishing a welfare home that has the capacity of only 50 people adds to the long list of ineffective solutions provided by the government.

In developing nations, every problem is linked to another, and identifying the root cause is difficult. Vagrants in Pakistan suffer from multidimensional poverty, and as elaborated in this paper, this marginalized community has different aspects and influences. Institutional weakness plays a vital role in undermining the issues of vagrants, and violent reactions has paved way as the sole solution. When state institutions are weak, and fail to address the problems of people at the grassroot level, problems of the most discriminated class never reach policymakers' desks. Instead of investing on eviction drives and stringent policies which claims that vagrants are criminals, the government can focus on facilitating them which is not only beneficial for vagrant families, rather in the long-term beneficial for the economy as well.

\section{Conclusion}

Developing nations are usually marked with a weak governance system, which subsequently leads to economic crisis and an unstable fiscal mechanism. These issues not only imprint on the economy of the state, rather they leave marks on the sociocultural setup of the population as well. Vagrancy is not a new phenomenon, but it is becoming a pressing 
issue in today's world. The increase in poverty and unemployment, political discrimination and social alienation leads to rise in vagrancy, which ultimately increases the begging culture and crime rate. For developing countries like Pakistan to get rid of the curse of vagrancy, many aspects have to be studied before framing a comprehensive policy. The foremost step is collection of data and identification of vagrants to have a realistic estimate of the vagrants and beggars in the country. Moreover, rather than making a reactionary policy, a preventive policy shall be designed.

Legislation regarding vagrants exist in Pakistan since many decades, which was adopted by the provinces, but the law itself claims that all vagrants are criminals and entitles the police to search them and arrest them without a warrant. This defines the extreme form of injustice inhibited upon the poorest class of the society. The state shall provide for the people opportunities to gain an income from, rather than belittling ad arresting them. For the cases in which vagrants are drug addicts or disabled, a separate criterion shall be established to handle them with standardized procedure. A sensitized police force shall be raised to handle them in a specialized manner.

The curse of vagrancy will not disappear after passage of one or a few legislations. The bottlenecks in implementation shall be identified, and with the help of institutional coordination resolved.

\section{References}

Legislation.Gov.Uk. (2020). Vagrancy Act $1824 . \quad$ [Online] Available At: Https://Www.Legislation.Gov.Uk/Ukpga/Geo4/5/83/Contents [Accessed 3 Mar. 2020].

Vagrancy | Law.” Encyclopedia Britannica, Www.Britannica.Com/Topic/Vagrancy. Accessed 3 Mar. 2020.

DFID Project No. R7905

Hill, Cameron. Homelessness And Violence The Impact Of Violence On Homelessness In Scotland Homelessness And Violence The Impact Of Violence On Homelessness In Scotland.

Azam, Nadia. Beggarization: Beggary As An Organized Crime In Pakistan. Nov. 2011.

“Global Homelessness Statistics - Homeless World Cup.”Homeless World Cup, 12 Sept. 2018, Homelessworldcup.Org/Homelessness-Statistics/.

“Balochistan Drought Needs Assessment (BDNA) Report (February 2019) - Pakistan.” Reliefweb, 2019, Reliefweb.Int/Report/Pakistan/Balochistan-Drought-Needs-Assessment-Bdna-Report-February-2019.

"Pakistan's New Poverty Index Reveals That 4 Out Of 10 Pakistanis Live In Multidimensional Poverty." UNDP In Pakistan, 2016 ,

Www.Pk.Undp.Org/Content/Pakistan/En/Home/Presscenter/Pressreleases/2016/06/20/Pakistan-S-New-

Poverty-Index-Reveals-That-4-Out-Of-10-Pakistanis-Live-In-Multidimensional-Poverty.Html.

${ }^{1}$ Khoso, Abdullah. "Prevalence Rate And Causes Of Child Begging In Peshawar City." Www.Academia.Edu, Www.Academia.Edu/9841249/Prevalence_Rate_And_Causes_Of_Child_Begging_In_Peshawar_City.

Accessed 3 Mar. 2020.

Iqbal, Zafar. War On Terror And Challenges For Criminal Justice In Pakistan. 2016, P. 433, Prr.Hec.Gov.Pk/Jspui/Bitstream/123456789/8213/1/Zafar\%20NDU\%20thesis\%20after\%20def\%20for\%20sub mission\%2025\%20Aug\%2017.Pdf. Accessed 3 Mar. 2020.

Case Study Series AFGHANS IN PESHAWAR Migration, Settlements And Social Networks. 2006.

Alowaimer, Osama. "Causes, Effects And Issues Of Homeless People.” Journal Of Socialomics, Vol. 07, No. 03, 2018, 10.4172/2167-0358.1000223.

Lajoie, R (1998) 'Shelter from the Storm' Amnesty Action, Summer 1998: 6-8

WEST PAKISTAN VAGRANCY ORDINANCE, 1958. Punjabcode.Punjab.Gov.Pk/En/Show_Article/Ebtqo0igj3te85phfx.Z0Cf43KBV Xyzwemoneyygwno Hgruxb 0uo2 Ilgnaozs3ywbkofrnwjxqeu81uo47q--.

THE SIND VAGRANCY (AMENDMENT) ORDINANCE, 1983: Accessed From: Http://Sindhlaws.Gov.Pk/Setup/Publications_Sindhcode/PUB-15-000580.Pdf 
The

Balochistan

Vagrancy

Ordinance,

1958.

Accessed

From:

Http://Blncode.Pitb.Gov.Pk/Index/Showarticle/Ref/07104eae-2b56-4be9-830e-08d21610dbd9

The Punjab Vagrancy Ordinance 1958: Http://Punjablaws.Gov.Pk/Laws/94.Html

The Khyber Pakhtunkhwa Child Protection And Welfare Act, 2010. Accessed From: Http://Kp.Gov.Pk/Uploads/2016/02/2._Child_Protection_And_Welfare_Act,_2010_.Pdf

Swkpk. "Social Welfare Institutions." Swkpk, 2018, Swkpk.Gov.Pk/?Page_Id=1252.

Khoso, Abdullah. "Prevalence Rate And Causes Of Child Begging In Peshawar City." Www.Academia.Edu, Www.Academia.Edu/9841249/Prevalence_Rate_And_Causes_Of_Child_Begging_In_Peshawar_City.

Accessed 3 Mar. 2020.

“Beggars' Rehabilitation (Beggars' Home) | Social Welfare Department." Swd.Punjab.Gov.Pk, Swd.Punjab.Gov.Pk/Beggar_Rehabilitation. Accessed 4 Mar. 2020.

“Elderly Welfare Services.” Balochistan.Gov.Pk, 2017, Www.Swd.Balochistan.Gov.Pk/Elderly\%20welfare.Html. Accessed 4 Mar. 2020.

Daily Times. (2018). The disenfranchised gypsies. [online] Available at: https://dailytimes.com.pk/269470/thedisenfranchised-gypsies/ [Accessed 3 Nov. 2020].

www.pakistantoday.com.pk. (n.d.). The value of gypsies | Pakistan Today. [online] Available at: https://www.pakistantoday.com.pk/2011/08/01/the-value-of-gypsies/ [Accessed 3 Nov. 2020].

The Children and Young People's Commissioner Scotland. (n.d.). UNCRC Article 40. [online] Available at: https://cypcs.org.uk/rights/uncrc/articles/article-40/\#: :text=Article\%2040\%20of\%20the\%20UNCRC [Accessed 3 Nov. 2020].

Speak, S. (n.d.). Alternative Understandings of Homelessness in Developing Countries. Global Urban Research Unit.

Bibars Imam (1998) Street Children in Egypt: from home to street to inappropriate institutions. Environment and Urbanization Vol. 10 No. 1 April 1998 pp 201 - 216

Dupont, V. (1998) 'Mobility patterns and economic strategies of houseless people in Old Delhi' . Paper presented at the Communication au Seminaire Delhi Games, Use and control of the urban space: power games and actors strategies, Session 2 Population movement and structuring of the urban space. 3-4 April 1998

Ali, A. (2015). Meet the gypsies of Lahore. [online] DAWN.COM. Available at: https://www.dawn.com/news/1173232 [Accessed 3 Nov. 2020]. 